\title{
AN ANALYSIS OF IMAGERIES IN E.E. CUMMINGS' SELECTED POEMS
}

\author{
Leni Tiwiyanti \\ Universitas Indraprasta PGRI Jakarta \\ 085714142808 \\ lenitiwiyanti@gmail.com \\ Mu'thia Mubasyira \\ Universitas Indraprasta PGRI Jakarta \\ 089605314315 \\ muthia.mubasyira@yahoo.com
}

Received August 2,2020; Revised August 12, 2020; Approved Oct 15,2020

\begin{abstract}
This research analyzes the imageries used by E.E. Cummings in two poems by E.E. Cumming. He is a 20th century poet and novelist known for his unique style and structure. He considered himself a painter as well as a poet. Most of his poems are free verse in which he innovates a new style of writing which disregard any traditional rules and regulations of writing. The purpose of this research is to identify the types of imageries used in some of selected poems by E.E. Cummings and how the imageries are applied in the poems. The method used is qualitative descriptive method. The source of the data are two poems "All in Green" and "Your Little Voice". Imageries are used to make abstract ideas concrete and easier to communicate specially used in poems. From the analysis, there are only five types out of seven types of imageries found in both poems. The five types of of the imageries are visual, auditory, kinesthetic internal and gustatory imageries. Both techniques by description and figurative language are applied to build the imageries. There are nine imageries applied by using description technique and seven imageries with figurative language technique.
\end{abstract}

Keywords: poems, imagery, types of imagery, technique in building imagery

\begin{abstract}
ABSTRAK
Penelitian ini menganalisis citraan yang digunakan oleh E. E. Cummings dalam beberapa karya puisinya. Dia adalah penyair dan penulis novel abad 20 yang dikenal dengan gaya dan struktur yang unik. Dia menilai dirinya sebagai seorang pelukis dan juga penyair. Dalam sebagian besar karyanya, dia menggunakan larik lepas yakni berinovasi dengan gaya menulis baru yang tidak megindahkan aturan atau ketentuan menulis tradisional. Tujuan dari penelitian untuk mengetahui jenis-jenis citraan puisi dan teknik yang digunakan untuk membangun dalam puisi karya E.E. Cummings. Sumber data diambil dari dua puisi berjudul "All in Green" and "Your Little Voice". Citraan digunakan untuk membuat ide abstrak menjadi nyata dan lebih mudah dikomunikasikan terutama dalam puisi. Dari Analisis, hanya terdapat lima dari tujuh jenis citraan yang digunakan dalam kedua puisi. Kelima citraan tersebut adalah citraan penglihatan, citraan pendengaran, citraan gerak, citraan perasaan dan citraan pengecapan. Kedua teknik deskripsi dan bahasa kiasan digunakan dalam membangun cintraan. Terdapat 9 citraan menggunakan teknik deskripsi dan tujuh citraan mengunakan teknik bahasa kiasan.
\end{abstract}


Keywords: puisi, citraan, tipe citraan, teknik membangun citraan

\section{INTRODUCTION}

\section{Background of Study}

Poetry as one of the literary genres is a form of literature that uses aesthetic qualities of language used by the poets to express their ideas. Poetry has become universal as it has existed almost in all period in almost every culture. As a medium of communication, poetry is created using a brief language that is easily differentiated from other literary works.

Poets express their thoughts from heart into a language that has rhthmic and a value of beauty. The language used is sometimes difficult to understand. The difficulties lie on the choices of words and structures used in poetry contain profoud meanings and it takes greater effort to comprehend the meaning.

One of the devices that poets use in building their intended message in their poems is imagery. Most poets will use images to amke abstract ideas concrete and easier to communicate and understood by the readers. The use of imagery intensifies the process of imagination in the readers' mind. In intensifictaion process, the elements of poetry play a function to create or build an image or a particular image. The sound and rhyme, the connection of the lyrics (lines) with other lyrics or a stanza with another stanza, and the choice of words and idioms have function to build a particular imagination or picture that the poem tries to build. Eventually, the imagination gives a whole meaning to the poem.

In poetry, the imagery is a composite of word that poets use to build various images. The image can be an object that we can see, hear, smell, taste touch or give physical sensation or feel any tension or movement in our body. Imagery is a tool to understand the poets' poetic message.

E.E. Cummings was a 20th century poet and novelist known for his unique structure and style. He was known as a painter as well as a poet. His poems were greatly influenced by contemporary Eurpean visual art, especially cubism. To make it possible, most of his poems are free verse in which he can innovate new style of writing which disregard any traditional rules and conventional regulations. This assures people to categorize him as one of the modern American poets. He was second most widely read poet in the United States. Most of his poems deal with the themes of relationships and love. 
The fact that E.E. Cummings poems are mostly written in an unusual way as he tries to break traditional rules in poetry writing. Readers with basic knowledge of poetry reading usually find the hardship to understand the message he conveys in his poems. There is, therefore, a need to analyze the type of imageries used in E.E. Cummings' selected poems and to analyze the technique that is used in applying the imageries. There are two poems selected entitled "All in Green" and "Your Little Voice". Based on the research problems mentioned above, the objective of the research is to find out the types of imageries that are applied in both poems and also the technique the poet applied in using the imageries.

\section{Formulation of the Research}

The followings are the research problems.

1. What are the types of poetic imageries used in the selected poems by E.E. Cummings?

2. How are the imageries built in the selected poems by E.E. Cummings?

\section{Objectives of the Research}

The followings are the objectives of the research.

1. To identify the types of poetuc imageris used in the selected poems by E.E. Cummings.

2. To identify how imageris are built in the selected poems by E.E. Cummings.

\section{RESEARCH METHOD}

\section{Research Design}

In this research, the researchers apply descriptive qualitative method. Since the research do not employ a statistical procedure, the result are in words not in numericalthe researcher used a descri[tive research method and the data in this study were described descriptively based on the facts. Ary (2010: 424) states that qualitative inquirer deals with data that are in the form of words or pictures rather than numbers and statistics According to (Silverman, 2004) qualitative data include observations, interviews, and life history accounts. Descriptive research also involves a collection of technique used specify, delineate, or describe naturally occurring phenomena without experimental manipulation.

\section{Source of the Data}

Data refers to facts or information used usually to analyxe the evidence gathered through experimentation or studies. The data are classified into two parts, they are primary data and secondary data. Primary data, according to Baxter \& Jack (2008) are original document, relics, 
remains, articles, or direct data which correlate with the research project. And secondary data is a data got from the other resources or results report from other person and supporting the primary. The primary data of this research is taken from three poems by E.E. Cummings entitled "All in Green" and "Your Little Voice". The theme of the two poems is love. E.E.

\section{Technique of Collecting Data}

The data of this research is derived from three poems by E.E. Cummings entitled "All in Green" and "Your Litle Voice". The researcher took the three poems as they have the same theme, love. The concept of 'love' is only seen as an abstract things, yet in E.E. Cummings poems we can see how he artistically bring the concept into alive to the readers. After the copy of the poems is obtained, the researcher read the whole poems in order to get the main message that E.E. Cummings conveys in each of the poems. Each line is analyzed and connected with the other lines in orther to get the thorough message. After that, the researcher search for lines that use imageries. After that, the researcher made a note on the imageries and the method that the poet uses in building the imageries.

\section{Technique of Analyzing Data}

After finding the imageries and also the method that the poet uses, the first step is identifying the types of imageries and also the type of method that each poem uses. The next step is analysing the imageries and also the method that the poet uses. The last is drawing conclusion from the analysis.

\section{Literature Review}

Poetry

Poetry is known as the genre in literature, and there are many definitions of poetry that stated by the expert around the world, some theories will explain are as follow: According to Roberts and Jacobs (2004: 609), "Poems and poetry are derived from the Greek word poiein, "to create or make," the idea being that poetry is a created artifact, a structure that develops from the human imagination and that is expressed rhythmically in words. Although poet originally meant the writer of any kind of literature, we now use the word exclusively to mean a person who writes poems." As mentioned above it can be concluded, poetry is something that created by the people who called a poet. There are as many definitions of poetry as the number of poets because 
Jurnal Pujangga Volume 6, Nomor 2, Desember 2020

ISSN P 2443-1478

ISSN E 2443-148

of its involvement in the power of imagination, emotions and peculiar use of language. A poem is made up of words how we think about and expresses everything in life and about life itself. It is a creation of a sound mind and it usually concerns itself with exciting and important things to the poet.

Also, Ibitola in David O (2012: 40) states that poetry is a form of writing stimulated by emotion and expressing a deep feeling that may be very difficult to explain in literary form. It is the act of uniting pleasure with truth by the help of imagination and reasoning. Poetry creates a vivid imagination expresses strong feelings and experiences using figurative language Okolo in David O (2012:40).

According to Dresden in Rati Mihardja (2011:18), "Puisi adalah sebuah dunia dalam kata. Isi yang terkandung dalam puisi merupakan cerminan pengalaman, pengetahuan, dan perasaan penyair yang membentuk sebuah dunia bernama puisi kesusastraan khususnya puisi adalah cabang seni yang paling sulit untuk dihayati secara langsung sebagai totalitas. Elemen-elemen seni ini ialah kata. Sebuah kata ialah satu unit totalitas utuh yang kuat berdiri sendiri. Puisi menjadi totalitas-totalitas baru dalam pembentukan-pembentukan baru dalam kalimat-kalimat yang telah mempunyai suatu urutan yang logis" (=Poetry is a world in words. Contents contained in poetry reflects the experience, knowledge, and feelings that make up a world poet named poem literature, especially poetry is the most difficult branch of art to be lived directly as a totality. The elements of this art are the word. A Word is a unit of totality that intact, strong stands on its own. Poetry becomes a new totality in the new establishment of sentences have had a logical sequence).

Based on the statement above, poetry is a creation of a poet, which involves all aspects of the life of poet that poured into text that uses figurative language, so the poem becomes a beautiful art. Poetry can tell a knowledge, experiences, and feelings, which comes from the poet.

Poetry is as one of the pieces of literature that can be studied from various aspects. Poetry can be studied from its structure and its elements, given that the poem is a structure composed of various elements. Throughout the era, poetry always experienced changes and developments.

\section{Imageries}

According to Steven Croft and Hellen Cross, an image is a language use in such a way as to help us to see, hear, feel, thing about or generally understand more clearly or vividly what is being said or the impression that the writer wishes to convey. 
Siswantoro explains that imagery can be meant as a mental picture, a picture, portrait or picture illusion created as a result of a reader's reaction in understanding the poem. Imagery emerges as a process to continue imagism developing an active reader to find explicit meanings in the text. To find the imagery, the readers must have good readings supported by the mastery of vocabulary, grammar, and cultural aspects. The readers have to be aware that the text is not our language, so we must adjust with enthusiasm the other text. Because of that the readers will be able to understand imagery by having a good participant with cognitive and emotional.

Laurence Perrine and Thomas explain that the word 'image' perhaps most often suggest a mental picture, something sense in the mind's eye. Therefore visual imagery is the kind of imagery that occurs most frequently in poetry. An image also represents a sound (auditory imagery); a smell (olfactory imagery); a taste (gustatory imagery); touch, such as hardness, softness, wetness, or heat and cold (tactile imagery); an internal sensation, such as hunger, thirst, fatigue, or nausea (organic imagery); or movement or tension in the muscles or joints (kinesthetic imagery).

Imagery usually calls a mental picture in a poem, where the readers can experience what the poem says. Essentially the true "meaning" of a poem lies in the total effect that it has upon the readers. Very often that effect stimulates a response which is not just a reaction to what poet has to say, but which draws on the readers' intellectual and emotional experience. Imagery can be of central importance in creating this response within the readers.

The image function is: to provide a clear picture, to create a special atmosphere, making life images and thoughts and senses and also to attract the readers to poetry.

\section{Kinds of Imagery}

Visual Imagery

Ahmad Badrun explains that visual imagery is an imagery which relates to the visual imagination and it is a kind of imagery that appears mostly in the poem because almost words represented in the poem are basically seeable. Sometimes, that seen in the mind eye which called by sight effect. Without visual imagery, a poem may hard to produce. For example:

Continuous as the stars that shine And twinkle on the Milky Way

They stretched in never-ending line Along the margin of a bay

Then thousand saw I at glance

Tossing their heads in sprightly dance

In our imagination, appear the daffodil stretches along line like the start that shine on the Milky Way. The daffodils stretched in never ending line along the margin of a bay. 


\section{Auditory imagery}

Auditory imagery is an imagery which relates to the auditory. This image represents sounds like words "buzzing, tinkling, chiming" and others related to the sound. This imagery is developed by the poet to make an auditory imaginative in poem. The auditory imagery that evokes in poem is not like auditory perception. It means, when the reader reads it, he only fell the sense of hearing but not really hearing in purpose. For example:

Hear the sledges with the bells-With silver bell!

What a world of merriment their melody foretells!

How they are tinkle, tinkle, tinkle,

The speaker invites us to hear the bells. The silver bells not iron or the copper bells, it makes the bell more melodious, then the start follows the bell jingle. The reader can feel strong sense of hearing in this poem.

Tactile imagery

Tactile imagery is an imagery which relates to tactile sense such as cold and warm. This imagery has relationship with the temperature like heat and cold or our touch sense. For example:

\section{A dungeon horrible, on all sides round, As one great furnace flamed}

These two simple lines bring the reader to fell the heat of hell, which is described like as dungeon. We will fell stuffy and tight, then all wall around the dungeon feel like a great furnace flamed.

\section{Olfactory imagery}

Olfactory imagery is an imagery which relates to olfactory or smelling sense like 'fragrant, unpleasant smell and the others related to the aroma. For example in Robert Frost poem "Out Out":

The buzz-saw snarled and rattled in the yard

And made dust and dropped stove-length sticks of wood, Sweet-scented stuff when the breeze drew across it.

In the first line, the speaker invites the reader to hear the buzz-saw snarled which is rattled in the yard. Then, in the second line, the readers will see the dust and dropped stove-length sticks of wood. Finally, in line three this are made a sweet- scented when the wind blew across it. Olfactory imagery appears in the third line, and the first and the second line which were contained as a way to bring the reader to feel smell sense in this poetry. 


\section{Gustatory imagery}

Gustatory imagery is an imagery which relates to the taste such as sweet and briny and others related to the flavor. For example: She is as sweet as red apple, the word "Apple" represent sweet taste to our imagination.

\section{Organic imagery}

Organic imagery is an imagery which relates to internal sensation of human body such hunger, thirst, pain, etc. for example:

"O where have ye been, Lord randal, my son?

"O where have ye been, my handsome young man?"

"I here been to the wild wood; mother, make my bed soon, For I'm weary will hunting, and fain wald lie down".

"Where gat ye your dinner, Lord randal, my son? Where gat your dinner, my handsome young man?"

"I dined will my true-love; mother, make my bed soon, For I'm weary will hunting, and fain wald lie down".

We can feel how weary Lord Randal is and how he wants to lie down! we can feel it through the question asked by his mother to him such as in line "..O where have ye been, Lord Randal, my son..." but the Lord Randal just say “..i dined will my true love;, mother, make my bed soon, For I'm weary will hunting, and fain wald lie down". These lines describe how tired Lord Randal is! This imagery that is built by speaker calls our imagination up to feel as same as the speaker.

Kinesthetic imagery

Kinesthetic imagery conveys a sense of movement or tension in the muscles or joints. In the ghost house could be studied how the poet describes the kinesthetic imagery. The statement ...the black bats tumble and dart... impress us about it sense of movement or tension in the muscle or joints.

\section{The Technique to build Imageries}

Imagery is not simple to build. Using imageries in a poem takes an artistry of the poet. Nurgiantoro (2013: 411) states that there are basically two techniques a poet can use in building imageries. The techniques are by description and by figurative language. Giving description is the first technique that poet can use. In order to build the image, poets construct structures of words. However, unlike in prose, poets only use selected words and expressions to describe the 
Jurnal Pujangga Volume 6, Nomor 2, Desember 2020

ISSN P 2443-1478

ISSN E 2443-148

obejct that they want to convey. The second one is by figurative language. As imagery is seen as an effective way to build senses, and as poets can only use limited words and lines, poets commonly decide to use figurative language. The poem below shows how figurative language is used to build imagery.

\section{RESULT AND DISCUSSION}

\section{Analysis on Imageries in "All in green" and "Your Little Voice"}

The following is the table showing the types of imageries used in the poem "All in Green". There are 19 imageries found in 13 lines of the poem. The reseacrcher finds the are 13 visual imagery, 3 auditory, 1 kinesthetic and 2 organic.

Table 5.1

Imageries in "All in Green"

\begin{tabular}{|c|c|c|c|c|c|}
\hline No & Phrases & Stanza & Line & Words & $\begin{array}{l}\text { Types of } \\
\text { imagery }\end{array}$ \\
\hline 1 & All in green went my love riding & 1 & 1 & green & visual \\
\hline 2 & On a great horse of gold & 1 & 2 & gold & visual \\
\hline 3 & Into the silver dawn & 1 & 3 & silver & visual \\
\hline 4. & the merry deer ran before & 2 & 4 & merry & organic \\
\hline 5 & The swift red dear & 3 & 7 & swift & kinesthetic \\
\hline 6 & The swift red dear & 3 & 7 & red & visual \\
\hline 7 & $\begin{array}{l}\text { Four red roebuck at a white } \\
\text { water }\end{array}$ & 4 & 9 & red & visual \\
\hline 8 & $\begin{array}{l}\text { Four red roebuck at a white } \\
\text { water }\end{array}$ & 4 & 9 & white & visual \\
\hline 9 & The cruel bugle sang before & 4 & 10 & sang & auditory \\
\hline 10. & Riding the echo down & 5 & 12 & echo & auditory \\
\hline 11. & Four fleet does at a gold valley & 8 & 19 & gold & visual \\
\hline 12. & the famished arrow sang before. & 8 & 20 & sang & auditory \\
\hline 13. & $\begin{array}{l}\text { Paler be they than daunting } \\
\text { death }\end{array}$ & 9 & 26 & paler & visual \\
\hline 14. & The sleek slim deer & 9 & 27 & sleek & visual \\
\hline 15. & The sleek slim deer & 9 & 27 & slim & visual \\
\hline
\end{tabular}


Jurnal Pujangga Volume 6, Nomor 2, Desember 2020

ISSN P 2443-1478

ISSN E 2443-148

\begin{tabular}{|l|l|l|l|l|l|}
\hline 16. & The tall tense deer & 9 & 28 & tall & visual \\
\hline 17. & The tall tense deer & 9 & 28 & tense & organic \\
\hline 18. & $\begin{array}{l}\text { Four tall stags at the green } \\
\text { mountain }\end{array}$ & 10 & 29 & tall & visual \\
\hline 19. & $\begin{array}{l}\text { Four tall stags at the green } \\
\text { mountain }\end{array}$ & 10 & 29 & green & visual \\
\hline
\end{tabular}

The following is the table showing the types of imageries used in the poem "Your Little Voice". There are 16 imageries found in 11 lines of the poem. The reseacrcher finds the are 5 kinesthetic imageries, 4 organic imageries, 3 visual imagery, and 3 auditory.

Table 5.2

Imageries in "Your Little Voice"

\begin{tabular}{|c|c|c|c|c|}
\hline No & Phrases & Line & Words & Types of imagery \\
\hline 1. & Your little voice & 1 & little & auditory \\
\hline 2. & Dizzy & 4 & dizzy & organic \\
\hline 3. & $\begin{array}{l}\text { With the jostling and shouting } \\
\text { of merry flowers }\end{array}$ & 5 & jostling & kinesthetic \\
\hline 4. & $\begin{array}{l}\text { With the jostling and shouting } \\
\text { of merry flowers }\end{array}$ & 5 & shouting & auditory \\
\hline 5. & $\begin{array}{l}\text { With the jostling and shouting } \\
\text { of merry flowers }\end{array}$ & 5 & merry & organic \\
\hline 6. & $\begin{array}{l}\text { wee skipping high-heeled } \\
\text { flames }\end{array}$ & 6 & skipping & kinestethic \\
\hline 7. & wee skipping high-heeled flames & 6 & $\begin{array}{l}\text { high- } \\
\text { heeled }\end{array}$ & Visual \\
\hline 8. & or twinkling over to my side & 8 & twinkling & visual \\
\hline 9. & $\begin{array}{l}\text { I was whirled and tossed into } \\
\text { delicious dancing }\end{array}$ & 12 & whirled & kinesthetic \\
\hline 10 & $\begin{array}{l}\text { I was whirled and tossed into } \\
\text { delicious dancing }\end{array}$ & 12 & tossed & kinesthetic \\
\hline 11 & $\begin{array}{l}\text { I was whirled and tossed into } \\
\text { delicious dancing }\end{array}$ & 12 & delicious & gustatory \\
\hline
\end{tabular}


Jurnal Pujangga Volume 6, Nomor 2, Desember 2020

ISSN P 2443-1478

ISSN E 2443-148

\begin{tabular}{|l|l|l|l|l|}
\hline 12 & Up & 13 & up & kinestethic \\
\hline 13 & With pale important & 15 & pale & visual \\
\hline 14 & Starts and the humorous & 16 & $\begin{array}{l}\text { humorou } \\
\text { s }\end{array}$ & organic \\
\hline 15 & $\begin{array}{l}\text { How I was crazy how I cried } \\
\text { when I heard }\end{array}$ & 19 & crazy & organic \\
\hline 16 & Sweetly & 23 & sweetly & auditory \\
\hline
\end{tabular}

The Technique in building imageries

The following is the table showing the imageries found in both poems with the technique that the poet uses in building the imageries. From the table we can see how E.E. Cummings use both techniques in building the imageries in both poems.

Both techniques are used in the poem. The description is used in eleven imageries and the other seven numbers of imageries are using figurative language. The use of figurative as in "The merry deer ran before" belongs to personification as it give human qualites to an inhuman being, "deer". The rest imageries that use figurative langauge technique are also belong to personification. The imageries are "cruel", "sang", "pale", "sleek", "slim", "tall", and "tense". The poem "Your Litle Voice" also uses both techniques. The description is used in nine imageries and the other seven numbers of imageries are using figurative language. Therea re two types of figurative langauge used, personification and hyperbole. The use of figurative as in "With the jostling and shouting of merry flowers" belongs to personification as it give human qualites to an inhuman being, "flowers". The hyperbole is in the use the word "up" as it is exagerating to say that the speaker can fly up in the air just upon hearing the voice of his beloved woman. The rest of the imageries that use figurative language technique belong to personification. The imageries are "jostling", "shouting", "high-heeled", "pale", and "humorous".

\section{CONCLUSION AND SUGGESTION}

\section{Conclusion}


Referring to the aim and the result of the research, the researchers draw a conclusion as follows: There are only five types out of seven types of imageries found in both poems, "All in Green" and in 'Your Little Voice'. The five types of of the imageries are visual, auditory, kinesthetic internal and gustatory imageries.

In the first poem "All in Green", there are nineteen imageries. Visual imagery is the highest number which covers thirteen lines, three lines use auditory imagery, two organic imagery and one kinesthetic imagery. In the second poem, "Your Little Voice", there are sixteen imageries found in eleven lines of the poem. The reseacrcher finds the are five kinesthetic imageries, four organic imageries, three visual imagery, and three auditory.

In both poem, both techniques in building the imageries are used. There are eleven imageries which are built by using description technique and the rest eight imageries are with figuratuve language technique. The figurative language used is only personification. In the second poem, there are also both technique used. There are nine imageries using description technique and seven imageries use figurative language technique. However, different from the

previous one the second poem uses two types of figurative language, personification and hyperbole.

In short, to understand the poem in detail, the readers have to know the elements in the poem, such as intrinsic elements. Some important elements in a poem are imagery and figurative language. Imagery refers to the picture that we perceive with our mind's eyes, ears, nose, tongue, skin, and though we experience the duplicate word created by poetic language. This is a device by which the poet makes his meaning strong, clear and sure. The readers should also aware that there the use of figurative language is made to strengthen the readers' senses which are used to built up images.

\section{Suggestion}

Through this study, the writer suggests the readers who are interested in studying about poetry, especially in E.E. Cumming's poems, to study and understand his poems from different aspects such as the styistic, symbol, explication, theme, tone and mood, rime, etc. This is closely related to the complexity of messages that can be explained in the poems. The writer also suggests to the next researchers to conduct a research on different data and different theories or theycan analyze the use of imageries in other text type such as in novels, advertisements, songs, and etc. 


\section{REFERENCES}

Ary.D., Jacobs, L. C., Sorensen, C. K., \&Razavich, A. 2010. Introduction to Research in Education. 8th Edition. Belmont, CA: Wadsworth, Cengage Learning

Baxter, P., \& Jack, S. 2008. Qualitative Case Study Methodology: Study Design and Implementation for Novice Researchers. The Qualitative Report, 13(4), 544-559. http://doi.org/10.2174/1874434600802010058

David O, Fakeye. 2012. Genral Preference and Senior Secondary Schools Literaturein-English Achievement. Cross-Cultural Communication: Available at http://www.cscanada.net/index.php/ccc/article/view/j.ccc.192367002012080 4.1163 DOI: http://dx.doi.org/10.3968/j.ccc.1923670020120804.1163. Retrieved on Saturday 27th August 2016 17:22 WIB.

Nurgiyantoro, Burhan. 2013. Teori Pengkajian Fiksi. Yogyakarta. Gadjah Mada University Press.

Roberts, Edgar V. and Henry E.Jacobs. 2004. Literature : An Introduction to Reading and Writing. New York: Pretince Hall, inc.

Silverman, D. 2004. Qualitative Research: Theory, Method and Practice. Qualitative Research. http://doi.org/10.1073/pnas.0703993104. 